\title{
ROZPROSZONY EKSPERT A ROZPROSZONA BAZA DANYCH - BLOGI SCEPTYCZNE, NAUKOWE A STRUKTURY WIEDZY
}

\begin{abstract}
Nowak Andrzej W., Rozproszony ekspert a rozproszona baza danych - blogi sceptyczne, naukowe a struktury wiedzy [Distributed expert and distributed database - sceptical blogs and scientific structure of knowledge] edited by M. Krajewski - "Człowiek i Społeczeństwo", vol. XXXVI, iss. 2, Poznań 2013, pp. 257-275. Adam Mickiewicz University Press. ISBN 978-83-232-2672-7. ISSN 02393271.

The text analyzed a group of blogs. They are considered as an example of a distributed expert and a distributed database. In addition, they illustrate a well-functioning informal collective of producing knowledge. The text indicates the specific functioning of the debate around science and socioscientific controversies in Internet based public sphere. The functioning of grassroots experts and distributed databases should be considered as a reference in an effort the reform of official university based structures of knowledge. Crucial question is how to reconcile the dynamics of the activity created by the blogging platform of reliability achieved in the context of traditional knowledge structures.
\end{abstract}

Andrzej W. Nowak, Uniwersytet im. Adama Mickiewicza w Poznaniu, Instytut Filozofii, ul. Szamarzewskiego 89c, 60-568 Poznań, Poland.

\section{WSTĘP}

Celem tekstu jest pokazanie, w jaki sposób funkcjonuje zjawisko, które można określić jako „rozproszoną” (distributed) bazę danych. Analizując taką bazę, chcę pokazać, jak jest ona tworzona i wykorzystywana przez tzw. "rozproszonego" eksperta. Moim obszarem badawczym jest działalność oddolnej, samoorganizującej się grupy blogerów/blogerek, zwanej TTDKN1.

1 Skrót ten rozwijany jest jako Think Tank Dyskurs Kultura Nauka, ale nazwa miała genezę o dość przyziemnym charakterze - powstała w wyniku autorefleksji, wyrażonej mało cenzuralnym sformułowaniem: $w$ końcu jesteśmy think-tankiem do $k \ldots$ nędzy. To obcesowe wyrażenie może razić, jednakże jest ono istotne $\mathrm{z}$ teoretycznego punktu widzenia. Bruno Latour wskazywał na ważne rozróżnienie pomiędzy materią faktów (matters of fact) i materią rozważań, 
Środowisko wspomnianych blogerów/blogerek, wraz z zaprzyjaźnionymi blogami naukowymi i sceptycznymi, intensywnie zajmuje się zwalczaniem szkodliwych postaw irracjonalistycznych obecnych w polskiej sferze publicznej. Szczególnie intensywnie śledzą oni przejawy owych irracjonalistycznych postaw w polskim Internecie. Wspomniana wyżej grupa blogerów/blogerek, nie jest jednolita, nie formuje też spójnego środowiska. Mimo różnic wewnętrznych osoby te łączy jedno - jak sami to określają - walka z „Otchłanią". Pod tym terminem rozumieją obecne w sferze publicznej zjawiska, które swym charakterem wykraczają poza możliwość zrozumienia. Szczególnie intensywnym polem działalności są zagadnienia dotyczące tzw. medycyny alternatywnej, zwłaszcza polemika z ruchami antyszczepionkowymi².

Szczególnie ważkim naukowo zagadnieniem jest prześledzenie, $\mathrm{w}$ jaki sposób grupa blogów stała się samouczącą, poznającą wspólnotą. Wspólnota ta, specyficzny rozproszony system poznawczy, stała się już swoistym ekspertem $\mathrm{w}$ takich tematach, jak: polemika $\mathrm{z}$ ruchami antyszczepionkowymi, wskazywanie na absurdy medycyny alternatywnej, krytyka tzw. rewolucyjnych konserwatystów, szczególnie z otoczenia pisma i portalu internetowego „Fronda”.

\section{CZYM JEST ROZPROSZONE POZNANIE?}

Przez pojęcie „rozproszenia” („dystrybucji”) rozumiem emergentne procesy, które są efektem sieci powiązanych artefaktów, przedmiotów oraz osób. Omawiając to zagadnienie, odwołuję się w swoich założeniach do dwóch tradycji: teorii aktora-sieci i współczesnej kognitywistyki, szczególnie do odkryć Edwarda Hutchinsa ${ }^{3}$. „Rozproszone poznanie” wprowadzone zostało do szerszego obiegu przez tego właśnie autora. Hutchins zadał ważne pytanie dotyczące bliskiego mu zagadnienia pilotażu: Kto pilotuje

czyli kwestiami, które powodują nasze zatroskanie (matters of concern). Tradycyjne nauki społeczne mają tendencje do skupiania się na materii faktów. Niestety, z tego powodu umyka im możliwość uchwycenia wielu fenomenów. Przykładowo, oglądając świat z poziomu materii faktów, łatwo przeoczyć coś, co dopiero się rodzi. Innym przykładem są kontrowersje, które mogą się okazać czymś kluczowym w przyszłości, zaś pozostając na poziomie materii faktów, zostaną zredukowane wyłącznie do problemu do rozwiązania w perspektywie "tu i teraz". Analiza wspomnianych blogów pozwala na śledzenie zasadniczych dla dzisiejszego społeczeństwa polskiego osi sporów i kontrowersji naukowo-społecznych.

2 Ta ostatnia działalność doczekała się dostrzeżenia przez pisma głównego nurtu. W tygodniku „Polityka” redaktor Marcin Rotkiewicz oparł swą polemikę z przeciwniczką szczepień, prof. Ewą Majewską, na odniesieniach do blogów należących do wspomnianej „koalicji", http://www.polityka.pl/nauka/zdrowie/1529867,1,szczepionkowa-polemika.read [dostęp: 25.10.2012].

${ }^{3}$ E. Hutchins, Cognition in the Wild, Cambridge, MA 1995. 
samolot - kokpit, czyli urządzenia nawigacyjne, czy pilot? Tradycyjnie odpowiedź na pytanie o to, gdzie są ulokowane procesy poznawcze, rozpada się na dwie możliwości: pierwsza akcentuje ześrodkowanie na tradycyjnie pojmowanym podmiocie (fundamentalizm humanistyczny ${ }^{4}$ ), druga z kolei podkreśla rolę narzędzi, artefaktów, urządzeń (determinizm technologicz$n^{5}$ ). Odkrycie Hutchinsa polega na pokazaniu, że procesy poznawcze, które tradycyjnie były traktowane jako własność indywidualnego podmiotu, są traktowane jako efekt emergentnego procesu powstałego $\mathrm{w}$ ramach całego zespołu/asemblażu kokpitu i pilota.

Zwrot ku rozproszonemu poznaniu jest konsekwencją ewolucji, która zachodzi we współczesnej kognitywistyce oraz ma wpływ na obraz praktyk naukowych ${ }^{6}$. Procesy te można metaforycznie określić jako kres uzurpacji "skóry i czaszki"7. Inaczej rzecz ujmując, to procesy, w których umysł przestaje być utożsamiany z mózgiem. Kolejne etapy tej rewolucji poznawczej to zwrócenie uwagi na procesy ucieleśnionego poznania (embodied cognition) oraz poznania enaktywnego ${ }^{8}$. Podkreśla się tu znaczenie ciała oraz działania w środowisku jako koniecznych elementów współtworzących świadomy umysł. Poznanie rozproszone (distributed cognition) to kolejny, konsekwentny krok w opuszczaniu soliptycznej ślepej drogi, w którą zabrnęła filozofia zachodnia, szczególnie w swej analitycznej odmianie9.

Odkrycia współczesnej kognitywistyki w znacznej mierze potwierdzają tezy formułowane na gruncie teorii aktora-sieci oraz dziesiątki lat wcześniej

${ }^{4}$ Przez fundamentalizm humanistyczny rozumiem, za Krzysztofem Abriszewskim, stanowisko, które w podmiocie ludzkim i tylko w nim upatruje głównego czynnika zmian. Fundamentalizm humanistyczny wzdraga się przed uwzględnieniem czynników pozaludzkich jako kluczowych dla istnienia i spajania zbiorowości (społeczeństwa). Por. K. Abriszewski, Wszystko otwarte na nowo. Teoria Aktora-Sieci i filozofia kultury, Torun 2010, s. 143-149.

5 Tradycja determinizmu technologicznego nie jest niestety w Polsce wystarczająco obecna. Ostatnio zmienia się to dzięki serii wydawniczej „Communicare”, w której zostały wydane tak ważne dla tej tradycji prace, jak: J. Goody, Logika pisma a organizacja społeczeństwa, przekład, wstęp i redakcja G. Godlewski, Warszawa 2006; E.A. Havelock, Muza uczy sie pisać. Rozważania o oralności i piśmienności w kulturze Zachodu, przekład i wstęp P. Majewski, Warszawa 2006; D.R. Olson, Papierowy świat. Pojęciowe i poznawcze implikacje pisania i czytania, wstęp i redakcja naukowa G. Godlewski, Warszawa 2010.

${ }^{6}$ Por. E. Bińczyk, "Ucieleśnione" $i$ "rozproszone" poznanie a obraz praktyk naukowych, [w:] Nauka w filozofii. Oblicza obecności, red. S. Butryn, M. Czarnocka, W. Ługowski, A. Michalska, Warszawa 2011, s. 119-137.

7 A. Clark, D. Chalmers, Umyst rozszerzony, [w:] Analityczna metafizyka umystu. Najnowsze kontrowersje, red. M. Miłkowski, R. Poczobut, Warszawa 2008, s. 342-357.

${ }^{8}$ Osobą promującą na gruncie polskim enaktywizm jako paradygmat badawczy jest filozof-kognitywista Tomasz Komendziński (UMK).

9 Pisałem o tym szerzej w tekście: Ontological Imagination: Transcending Methodological Solipsism and the Promise of Interdisciplinary Studies, [w:] Language, Literacy, and Media Theory: Exploring the Cultural History of the Extended Mind, "Avant” 2013, vol. IV, iss. 2, s. 169-193. 
przez Ludwika Flecka. Ten ostatni jest szczególnie ważny, gdyż myślenie w kategorii kolektywu i stylu myślowego może być pomocne do połączenia badań we współczesnej kognitywistyce z tradycją rozwijaną $\mathrm{w}$ ramach społecznych studiów nad nauką i technologią oraz teorii aktora-sieci ${ }^{10}$.

\section{ROZPROSZONE POZNANIE A WSPÓLNOTA POZNAWCZA}

Jak wspomniałem powyżej, pojęcie aktywnej poznawczo wspólnoty nie jest nowe. Elementy takiego myślenia możemy znaleźć u Durkheima i innych wczesnych socjologów piszących o jakiejś formie społecznego "nadumysłu". Analizy te miały zasadniczo jedną poważną wadę: były zbyt ogólnikowe. Ponadto postulowane przez nie „poznanie społeczne” było opisywane w spekulatywny, mało empiryczny sposób. Dopiero prace Flecka pozwoliły na sformułowanie takiego rozumienia poznającej wspólnoty (badawczej), które przezwyciężało te ograniczenia. Myśliciel ten, mimo że wiele lat był zapomniany, dziś stał się na nowo odkrytym prekursorem społecznych studiów nad nauką i techniką. Jego prace nad "kolektywem myślowym" (Denkkolektiv) i „stylem myślowy" (Denkstill) współgrają z najnowszymi badaniami w nurcie społecznych badań nad nauką:

„[...] jeśli dokonamy już reinterpretacji Flecka w duchu etnografii laboratorium, to można spróbować pójść dalej: odszukać w pojęciu «kolektywu myślowego» zbieżności z «kulturami epistemicznymi» Knorr-Cetiny oraz kolektywem (zbiorowością ang. collective) Latoura, a następnie ponownie zapytać o relacje pomiędzy kolektywem a stylem myślowym. Czyż samo to zestawienie pojęć «styl myślowy» - «kolektyw myślowy» nie przywodzi na myśl owych dwóch nurtów badawczych - studiów nad nauką oraz kognitywistyki?"11.

Podążając tym tropem, możemy zaproponować pewien model rozproszonej wspólnoty, który za Fleckiem nazywać będę kolektywem myślowym.

"Grupa samoorganizujących się agentów, składa się z podmiotów o dynamicznej budowie (to znaczy podlega procesom samoregulacji i samoorganizacji, mówiąc językiem fizykalistycznym); jedynym sposobem na adekwatną analizę procesów poznawczych jest założenie, że członkowie takiej grupy funkcjonują na zasadzie sprzężenia kauzalnego"12.

\footnotetext{
${ }^{10}$ K. Abriszewski, Trzecia fala. Ludwik Fleck $i$ antropologia laboratorium, http://fleck. umcs.lublin.pl/teksty.abriszewski2009a.htm [dostęp: 25.10.2012].

11 Ibidem.

12 A. Clark, D. Charmes, op. cit., s. 342-357.
} 
Powyższy cytat pokazuje, w jaki sposób można zaproponować takie ujęcie kolektywu myślowego, które nie pozostaje na gruncie intuicji zdroworozsądkowych. Kolektyw myślowy to zatem grupa podmiotów (nieograniczających się jedynie do podmiotów ludzkich), aktywnych uczestników powiązanych procesami, które poprzez pętle sprzężeń zwrotnych powodują powstanie emergentnych zjawisk. Te z kolei pozwalają na pojawienie się nowego zjawiska, tradycyjnie za Fleckiem określanego jako styl myślowy, który możemy nazwać także kolektywną mapą mentalną. Mimo że mapa taka powstała $w$ ramach pewnego kolektywu, jest w pewnych aspektach od niego niezależna i zwrotnie determinuje to, $\mathrm{w}$ jaki sposób dany kolektyw działa. Stanowi ona swoiste apriori, matrycę poznawczą kształtującą myśli i działania uczestników kolektywu, mapę: „zawierająca «ślady» (traces) i wskaźniki naznaczających (stigmergy) działań, wypracowane w spektrum czasowym, pomocne przy wyznaczaniu priorytetów"13.

\section{STUDIUM PRZYPADKU: WYKORZYSTANIE BAZ DANYCH PRZEZ TTDKN ORAZ SAM KOLEKTYW JAKO BAZA DANYCH}

Kolektyw badawczy u Flecka dotyczył wspólnoty uczonych i ich otoczenia, mnie interesować będzie grupa, która nie spełnia tak rygorystycznej definicji. Jednak uważam, że mimo iż formalnie nie stanowi ona grupy uczonych, można określić TTDKN jako swoisty kolektyw badawczy/ poznawczy. Co więcej, uważam, że grupa tapełni z powodzeniem rolę eksperta, rozumianego jednak dość specyficznie - jako eksperta „rozproszonego" na wiele heterogenicznych głosów, blogów, komentarzy. W tym tekście zajmę się przede wszystkim tym, w jaki sposób TTDKN jako kolektyw poznawczy tworzy swą tożsamość, swój styl myślowy, konstruując własną kolektywną mapę z wykorzystaniem baz danych. Dodatkowym poziomem, który warto poddać analizie, jest sama TTDKN, traktowana jako baza danych. Notki na blogach, komentarze, dyskusje internetowe i ich zapisy na portalach społecznościowych same zaczęły stanowić bazę danych, unikatowy zapis toczonych dyskusji. Powstała $\mathrm{w}$ ten sposób szczególna mapa kontrowersji naukowo-społecznych, które w ostatnich latach były ważne dla polskiej "blogosfery". Co istotne, ta baza danych wykorzystywana jest przez osoby spoza grupy, a także przez samą grupę jako forma kolektywnej pamięci.

13 J. Podgórski, Główne założenia poznania rozproszonego a sposób opisywania procesów poznawczych w określonej wspólnocie, „Homo Communicativus” 2008, nr 1(3). 
Jak już wspominałem, grupa omawianych blogerów/blogerek stanowi środowisko samozwańczych ekspertów, którzy zwalczają szkodliwe, antynaukowe mity i postawy (antyszczepionkowcy, teorie spiskowe etc.). Działalność tę można przedstawić jako jeden z wyznaczników nowoczesności refleksywnej społeczeństwa ryzyka. Wraz z kresem stabilnej narracji nowoczesnej refleksyjni członkowie społeczeństwa, obywatele $\mathrm{w}$ debatach i aktywnościach społecznych sami współtworzą kształt społeczeństwa. Takie pojęcia, jak rozwój, postęp, definicje podstawowych celów społecznych, nie są już wyznaczane przez stabilne systemy - szkolnictwo, naukę czy system medyczny. Te silne niegdyś ośrodki, produkujące reżimy prawdy, dziś napotykają konkurencję, pojawiają się inne ośrodki produkcji wiedzy (a zatem i reżimów władzy). Pole walki nie jest już tak proste jak niegdyś, nie ma łatwego podziału na siły postępu i zacofanych. Pole walki jest złożone, a sojusze nieoczekiwane ${ }^{14}$. Ulrich Beck określił to jako wojny o kształt nowoczesności:

„Wybuchające konflikty przyjmują w tym sensie charakter cywilizacyjnych walk wyznaniowych o właściwą drogę nowoczesności"15.

Spory w wojnach kulturowych (będących częścią tego zjawiska) dotyczą między innymi takich zagadnien, jak: homoseksualizm, feminizm, wojny o naukę (Science Wars) ${ }^{16}$, scjentyzm versus postmodernizm, realizm/obiektywizm versus konstruktywizm, ruchy antyszczepionkowe, homeopatia, zdrowa żywność (Codex Alimentarium), globalne ocieplenie, ewolucjonizm/ kreacjonizm, aborcja/in vitro/badania prenatalne. Zwrócenie uwagi na "rozproszony" charakter naszego kolektywu jest o tyle ważne, iż współcześni irracjonaliści, tzw. "Otchłan", także stanowią wysoce niejednorodne środowisko. Wyprzedzając tok argumentacji, wydaje się, że taki sieciowy rozproszony ekspert/baza danych, jakim jest grupa blogerów/blogerek skupionych pod szyldem TTDKN, jest adekwatną odpowiedzią na sposób funkcjonowania współczesnych irracjonalistów. Przykładowo, w przypadku sprzeciwu wobec szczepień „koalicja” antyszczepionkowców obejmuje: ekologów "głębokich" i radykalnych (szczepienia jako nienaturalne), zatrwożonych rodziców (w tym rodziców dzieci autystycznych), fundamentalistów religijnych, dla których szczepienia są niezgodne z wolą bożą. Zwolennicy „medycyny naturalnej” - „alternatywnej” to także libertarianie/neoliberalni

14 Piszący te słowa wielokrotnie napotykał poważne problemy, gdy okazywało się, że racjonaliści i scjentyści, którzy byli sojusznikami w walce $\mathrm{z}$ ruchem antyszczepionkowym, byli jednocześnie przedstawicielami stanowisk eurocentrycznych, mizoginicznych.

${ }^{15}$ U. Beck, Spoteczeństwo ryzyka, Warszawa 2002, s. 53.

16 Por. B. Tuchańska, O Sokalu z Bricmontem, Latourze io tym, co z tego (nie) wynika, "Nauka” 2006, nr 1, s. 93-111. 
fundamentaliści, dla których szczepienia to przymus znienawidzonego państwa, niektórzy alterglobaliści, dla których szczepienia to narzędzie globalnych korporacji. Nie wyczerpałem tu wszystkich stanowisk, widać jednakże, jak są one różnorodne oraz jak wielopłaszczyznowa musi być krytyka ruchu antyszczepionkowego. Zwróćmy uwagę na bezradność tradycyjnych struktur wiedzy wobec takiego zagadnienia. Kto powinien analizować ruch antyszczepionkowy: specjaliści od medycyny, socjolodzy, kulturoznawcy, ekonomiści, politolodzy? Stawiam w tym momencie mocną tezę, że opisywana poniżej struktura i sposób działania rozproszonego eksperta/bazy danych, jakim jest TTDKN, powinna stanowić punkt odniesienia dla przyszłych działań reformujących nauki społeczne ${ }^{17}$.

\section{KONTROWERSJE: OMIJAĆ CZY WCHODZIĆ?}

Ważnym problemem, który trapi sferę publiczną, są sposoby redukowania i rozwiązywania konfliktów i kontrowersji ${ }^{18}$. Kontrowersje i konflikty mogą oddziaływać na debatę publiczną przynajmniej dwojako: pozytywnie - wtedy służą jako sonda, probierz, wskazują na ważne, często dramatyczne problemy trapiące nasze społeczeństwa; mogą mieć jednak także wpływ negatywny, gdy rozrywając konsensus, wprowadzają zamęt, zwiększają poziom agresji, podmywają poziom bezpieczeństwa ontologicznego. Dlatego tak istotne jest to, jak umiemy sobie radzić z kontrowersjami. Gdy je tylko omijamy, wtedy istnieje ryzyko, że nie zauważymy ważkich zagrożeń, co może zaważyć na losie całego społeczeństwa ${ }^{19}$.

17 Przyszłą i konieczną reformę nauk społecznych, moim zdaniem, powinny wyznaczać dwa projekty: zwrot fronetyczny proponowany przez Benta Flyvbjerga oraz późne prace Immanuela Wallersteina. Por. B. Flyvbjerg, Making Social Science Matter: Why Social Inquiry Fails and How It Can Succeed Again, Cambridge 2001; Wyzwania wobec nauk spotecznych u progu XXI wieku, do druku przygotował A. Flis, Kraków 1999 - publikacja ta zawiera tekst Raportu Komisji Gulbenkiana na Rzecz Restrukturyzacji Nauk Społecznych zatytułowany Otwórzmy nauki społeczne, Immanuel Wallerstein był przewodniczącym tej komisji

18 Por. P. Stankiewicz, Ryzyko i konflikt. Strategie zarzadzania konfliktami technologicznymi $w$ Polsce, niepublikowana praca doktorska dostępna online: http://polska-wolna-od-gmo. org/doc/Piotr_Stankiewicz_PhD.pdf [dostęp: 25.10.2012].

19 Świetnym przykładem mogą być losy osadnictwa wikingów na Grenlandii. Jared Diamond opisuje, jak tradycyjne sposoby gospodarowania, w tym niechęć do rybołówstwa, spowodowały upadek wikińskich kolonii. Brak mechanizmów wzniecania i kontrolowania kontrowersji uniemożliwił wikingom zrewidowanie własnych obyczajów. Oczywiście zbyt silne kontrowersje też nie byłyby pożądane. Mogłyby one doprowadzić do konfliktu, np. wojny domowej, która także wyniszczyłaby osadników. Por. J. Diamond, Upadek, Warszawa 2007. 
„Kontrowersyjne są już nie techniczne innowacje same w sobie, lecz formy możliwości porozumienia się co do uregulowanego sposobu obchodzenia się z nimi. W społeczeństwie, w którym obszar tego, co [...] kontrowersyjne, rozciąga się na sam postęp, zdolność do regulowania i instytucjonalizowania konfliktów staje się podstawową kwestią społeczną"20.

Zbytnie wchodzenie i rozniecanie kontrowersji grozi z kolei rozerwaniem społeczeństwa, wprowadzeniem konfliktów na taki poziom, że rozpadnie się ono na samoorganizujące się subspołeczeństwa, poddane spiralnie nakręcającym się i niekończącym wojnom. Może to być równie wyniszczające jak pułapki, w jakie wpadają tradycyjne społeczeństwa oparte na kodzie honorowym. Takie społeczności właściwie nie mogą funkcjonować z powodu ciągnących się często przez dziesiątki lat wojen rodowych (wynikających z konieczności zemsty). Dlatego zasadnicze jest wypracowanie nieredukcyjnych sposobów rozwiązywania konfliktów, tak aby maksymalnie wyzyskać informacyjny potencjał konfliktu, a jednocześnie nie rozerwać społecznego konsensusu. Najważniejsze jest takie wypracowanie sposobów regulacji kontrowersji, aby zminimalizować nieświadome wytwarzanie obszarów tworzenia niewiedzy.

Warto w tym miejscu zdecydowanie wyartykułować pytanie, czy redukcja złożoności, np. przez bazę danych, jest w ogóle pożądana. Jak pamiętamy, choćby z lektur Michela Foucaulta, Iana Hackinga czy Bruno Latoura, redukcja złożoności to proces zamykania w czarne skrzynki, "blackboxing”, w związku z czym jest to proces o dużej wadze politycznej. Zamknięcie w czarną skrzynkę ucina dyskusję o kontrowersji. Domykanie kontrowersji to moment silnie polityczny, nacechowany przemocą. Oczywiście przemoc traktuje tu jako kategorię filozoficzną, a nie zjawisko fizyczne ${ }^{21}$. Dlatego ważne jest pytanie o wypracowanie nieredukcyjnego sposobu rozpoznawania i mapowania kontrowersji. W niniejszym tekście wychodzę z założenia, że TTDKN jest częściowo takim narzędziem. Ponadto twierdzę, iż oddolność tej inicjatywy i jej pozaformalny charakter powodują, że częściej udaje się uniknąć „redukcyjnego modelu rozwiązywania konfliktów” w przypadku Glogerów niż w ramach rozwiązań powiązanych z klasycznymi figurami eksperckimi.

${ }^{20}$ A. Evers, H. Nowotny, Über den Umgang mit Unsicherheit. Die Entdeckung der Gestaltbarkeit von Gesellschaft, Frankfurt am Main 1987, s. 247, cyt. za: P. Stankiewicz, op. cit., s. 87.

${ }^{21}$ Por. A. Zybertowicz, Przemoc i poznanie: studium z nie-klasycznej socjologii wiedzy, Toruń 1995 


\section{NIEREDUKCYJNA BAZA DANYCH?}

Jak już zauważyłem wyżej, traktuję analizowane blogi jako nieredukcyjną bazę danych, służącą także jako narzędzie mapowania aktualnych kontrowersji naukowo-społecznych. Nieredukcyjny charakter TTDKN wynika w dużej mierze z tego, że działa ona ${ }^{22}$ "w czasie rzeczywistym”. Blogi są $w$ dużej mierze otwartym ${ }^{23}$ forum dyskusji. Oczywiście wewnątrz blogów TTDKN-owskich istnieją silne tendencje do tworzenia klik, koterii. Jednakże otwartość wymuszona jest poprzez otoczenie. To bierze się przede wszystkim z wpływu blogerów mniej związanych z „rdzeniem” TTDKN, którzy wprowadzają nowe wątki i powodują zmianę w konfiguracji analizowanej sieci blogów. Drugim czynnikiem jest sama intensywnie zmieniającą się natura kontrowersji społeczno-naukowych. Sojusz zawarty przeciw antyszczepionkowcom może się rozpaść, gdy dyskusja zacznie się toczyć na temat praw kobiet w Iranie. Tarcia wewnątrz luźnej konfederacji blogerów powodowały, że wielokrotnie formułowano pytanie, czy TTDKN w ogóle istnieje. Omawiany „rozproszony ekspert” istnieje, pojawia się zwykle wtedy, gdy mamy do czynienia z tzw. dobrym "flejmem”, czyli wielowątkową, rozpalającą do białości dyskusją.

Wydaje się, że ten efemeryczny, aktualizowany przez dyskusję sposób istnienia bazy danych (oraz sprężonego $\mathrm{z}$ nią rozproszonego eksperta) dobrze oddaje to, co Bruno Latour określa jako tzw. materię rozważań (matters of concern) w odróżnieniu do tematów, którymi zajmuje się klasyczna socjologia, czyli materii faktów (matters of facts). Materia faktów to analizowanie zjawisk zamkniętych, utrwalonych $\mathrm{w}$ dawniej odbytych (lub nieodbytych) dyskusjach. Kontrowersje, które kiedyś rozpalały, już wygasły, problemy ukryły się w stabilnych definicjach tego, co faktyczne. Aby wykryć niegdysiejsze kontrowersje, należy dopiero podjąć duży wysiłek rozmontowania "czarnych skrzynek", pokazania, że fakty, które dziś wydają się stabilne i oczywiste, są niegdysiejszym sporem, który wygasł, został zakończony. Nauki społeczne $\mathrm{w}$ aktualnym kształcie dyscyplinarnym mają poważny problem ze śledzeniem materii rozważań. Dzieje się tak częściowo z powodu odziedziczonej po XIX wieku struktury dyscyplinarnej. Dyscypliny utworzone przez przygodne warunki historyczne "zamroziły" owe warunki i zwrotnie narzucają teraz sposób „ontologizowania” świata. Akademicki podział pracy powoduje, że wiele kontrowersji naukowych wymyka się, jest

${ }^{22} \mathrm{~W}$ tekście TTDKN będzie dorozumiany jako "grupa blogerów i blogerek", stąd użycie zaimka „ona".

${ }^{23}$ Oczywiście owa „otwartość” wyznaczana jest skłonnością danego blogera do stosowania narzędzi porządkujących dyskusję. Wybrani uczestnicy blogosfery różnie definiują zakres swobody wypowiedzi. 
z trudem tematyzowanych przez ekspertów. Wallerstein i inni członkowie komisji Gulbenkiana proponowali m.in. jako środek zaradczy podwójne mianowanie profesorów oraz wzorowanie się na studiach regionalnych - to problemy, a nie dyscypliny, zdaniem tych badaczy, mają wyznaczać strukturę zespołów badawczych. Niestety, w praktyce mamy do czynienia raczej z procesem odwrotnym. Wagę badań toczonych w trybie materii rozważań podkreśla poniższy cytat:

"Grecy mieli dla «rzeczy» stosowny termin «pragmata», tzn. to, z czym ma się do czynienia w zatroskanym obchodzie (praxis). Specyficzny «pragmatyczny» charakter owych «pragmata» pozostawili jednak pod względem ontologicznym i określili je «najpierw» jako «jedynie rzeczy»" 24 .

Widzimy zatem, że zgodnie z ontologią codzienności Heideggera ${ }^{25}$ materia rozważań jest zasadniczym elementem konstruującym nasz świat życia. Problemem jest to, że łatwo o tym zapominamy, skupiając się na już utrwalonych typizacjach i instytucjach społecznych. Latour podkreśla wagę badań w duchu ANT (actor-network theory - teorii aktora-sieci), gdyż pozwalają one uchwytywać te ulotne momenty konstytucji bytu społecznego. Kontrowersje naukowo-społeczne i toczące się wokół nich dyskusje internetowe są doskonałym poligonem, laboratorium, w którym badacz społeczny może obserwować rozplatanie się i splatanie na nowo tego, co społeczne.

\section{FUNKCJONOWANIE BLOGÓW JAKO BAZY DANYCH}

Blogi naukowe, sceptyczne, blogi linkujące się wzajemnie i tworzące TTDKN, wytworzyły swoistą bazę danych. Stało się tak w dużej mierze dzięki istnieniu kilku silnych blogów - gwiazd socjometrycznych. Tutaj skoncentruję się na jednym z blogów - prowadzonym przez Bartka Kuzię (blogdebart.pl) ${ }^{26}$.

Specyfiką bazy danych, jaką jest środowisko-sieć omawianych blogów, jest to, że w ramach dyskusji prowadzonych na owych blogach uzusem, kanonem dobrej debaty jest posługiwanie się bazami danych, szczególnie bazą publikacji medycznych - PUBMED. W obrębie dyskusji TTDKN normą,

\footnotetext{
${ }^{24}$ M. Heidegger, Bycie i czas, Warszawa 1994, s. 96 [67/68].

${ }_{25}$ Por. A.W. Nowak, Doświadczenie codzienności u Martina Heideggera, [w:] Doświadczenie, red. T. Buksiński, Poznań 2001, s. 163-177.

${ }^{26}$ Blogdebart.pl z największym zaangażowaniem podejmuje najbardziej interesujące mnie dyskusje z pogranicza nauki, zwłaszcza medycyny. Innymi ważnymi gwiazdami socjometrycznymi są blog dziennikarza "Gazety Wyborczej” Wojciecha Orlińskiego (wo.blox.pl) oraz blog Michała Radomira Wiśniewskiego (mrw.blox.pl).
} 
dość ściśle przestrzeganą (szczególnie na blogdebart.pl), jest używanie oficjalnych baz danych jako argumentu w dyskusji - dyskusja odbywa się często z użyciem linków do "tradycyjnych baz danych". Swoista netykieta podkreślana przez dyskutantów wymaga, aby informacje zamieszczane $\mathrm{w}$ komentarzach były potwierdzane wiarygodnymi linkami. Komentarze bez linków nie są traktowane poważnie. Nie oznacza to jednak, że można zamieszczać linki tylko jako ozdobniki i graficzny znak własnej erudycji. Śledzenie zalinkowanych $w$ dyskusji treści jest powszechne i stało się jednym z ważniejszych mechanizmów samouczenia się naszego "rozproszonego eksperta". W trakcie wieloletnich dyskusji niektóre linki, odniesienia do baz danych stały się powszechnie znane i wbudowały gładko w procesy komunikacji. Sposób dyskusji, który wymaga nieustannego korzystania $\mathrm{z}$ baz danych i potwierdzania własnych sądów poprzez linkowanie wiarygodnych źródeł, spowodował, że dyskusje toczone na wspomnianych blogach osiągnęły bardzo wysoki poziom argumentacyjny, często przekraczający poziom argumentacji w tzw. tradycyjnej nauce. Dobrze to było widać, gdy na blogdebart.pl oraz na kilku blogach pokrewnych sprawdzano wiarygodność twierdzeń prof. Majewskiej o szkodliwości szczepionek. Różnica w poziomie argumentacji była przytłaczająca. Co ważne, to nie "naukowa” prof. Majewska prezentowała wyższy, lepszy sposób argumentacji. Sieć połączonych ze sobą blogów stanowi nie tylko swoisty poligon dyskusji, lecz także bazę danych ze swoją historią, pamięcią etc. Wagi temu dodaje intensywność, z jaką odbywają się dyskusje. Warto tu wspomnieć, że najdłuższe dyskusje odbywały się właśnie na blogdebart.pl, częściowo ze względu na wagę tej gwiazdy socjometrycznej, a częściowo ze względu na wyjątkowo łatwy i przejrzysty sposób komentowania. Autor blogdebart.pl świadomie wykorzystuje potencjał swojego blogu jako kluczowego dla całości tej rozdyskutowanej podsieci. Ważnym aspektem jest też to, że sam blog zaczyna stanowić bazę danych. Warto przyjrzeć się długości dyskusji pod poszczególnymi notkami, gdzie mamy do czynienia z bazą danych oraz otwartym „archiwum” dyskusji:

- http://blogdebart.pl/2010/03/17/dalsze-przygody-swinki-w-newjersey/ - liczba komentarzy: 2131

- http://blogdebart.pl/2010/07/29/witamina-w-cudzyslowie/- liczba komentarzy: 2351

- http://blogdebart.pl/2009/09/25/jak-pije-sie-nafte/- liczba komentarzy: 1693

- http://blogdebart.pl/2011/05/25/starozytne-madrosci-profesora/liczba komentarzy: 1901.

Liczba komentarzy nie oznacza, że wszystkie one są poświęcone merytorycznej dyskusji na temat przedstawiony w notce - wiele $\mathrm{z}$ nich dotyczy 
tematów pobocznych (off-topic). Komentarze są zapisami wielomiesięcznych dyskusji, które oprócz komentarzy mających charakter merytoryczny, stanowią też zapis historii samego dyskutującego kolektywu, podejmującego często także tematy poboczne. Choć odsetek komentarzy czysto merytorycznych stanowi tylko niewielką część całości, to i tak bez trudu można zauważyć, iż intensywność debaty jest nie do porównania $\mathrm{z}$ debatami prowadzonymi w ramach kanałów komunikacyjnych w "oficjalnych" naukach społecznych. Sprzężenia zwrotne i konsolidacja środowiska dyskutantów w przypadku środowiska blogerów mają ważkie konsekwencje. Atomizacja polskiego środowiska naukowego (szczególnie silna $\mathrm{w}$ obrębie filozofii) oraz nikłe kanały komunikacyjne (np. brak punktów za recenzje, opinie, debaty) powodują, że "domyślnym” twórcą jest samotny badacz. Blogi w naturalny sposób premiują usieciowioną aktywność27. Blogi ",samotne", niepotrafiące włączyć się w szersze kręgi dyskutujących, blogi nietworzące ekosystemu regularnych komentujących dyskutantów szybko „obumierają". Sieci blogerów są szczególnym wyzwaniem dla struktur wiedzy tworzonych $\mathrm{w}$ obrębie nauk społecznych. Tu przeciwstawienie "samotny badacz" versus „sieciowy rozproszony kolektyw badawczy” widać najsilniej. $\mathrm{W}$ naukach przyrodniczych tworzenie zespołów badawczych połączonych silnie pętlami komunikacyjnymi sprzężonymi zwrotnie jest naturalną pochodną pracy w laboratoriach. $W$ tych ostatnich nie sposób wyobrazić sobie pracy poza zespołem czy kolektywem badawczym. Można zaryzykować tezę, że spora liczba blogujących „po godzinach" naukowców z obszaru nauk przyrodniczych to efekt przyzwyczajenia do kolektywnego, sieciowego sposobu pracy. Zmiana w organizacji struktur wiedzy, sposobie pracy, zwiększenie udziału zespołów, sieci, kolektywów badawczych miałyby prawdopodobnie zwrotny wpływ na popularyzację takich ujęć nauki, które źródeł odkryć, innowacji szukają raczej w zbiorowych podmiotach (wraz $\mathrm{z}$ artefaktami) niż w jednostkach.

Kolejnym ważnym elementem tej specyficznej bazy danych, jaką stanową blogi wokół TTDKN, są "flejmy” (flame wars). Dyskusje tego typu mogą angażować jedynie członków grupy albo też toczyć się pomiędzy członkami grupy a innymi użytkownikami polskiego Internetu. Dyskusje takie mają funkcję dwojaką: po pierwsze, konsolidują i przeobrażają grupę (dyskusje „wewnątrz TTDKN-owe"), po drugie, określają granice tożsamości grupy $\mathrm{w}$ jej relacji $\mathrm{z}$ „,zewnętrzem". Oddaje to dobrze napięcie pomiędzy autopoietycznym i allopoietycznym modusem funkcjonowania naszego „rozproszonego eksperta". Intensywne debaty toczone w Internecie powodują, że sieć

${ }^{27} \mathrm{O}$ usieciowieniu i wytwarzaniu wspólnotowych więzi jako jednym z najważniejszych źródeł innowacyjności por. S. Johnson, Where Good Ideas Come From: The Natural History of Innovation, Riverhead Hardcover 2010. 
blogów ma dużo bardziej allopoietyczny charakter niż tradycyjne nauki społeczne. Allopoietyczny charakter "bazy danych” powoduje, że jest ona bardziej niż tradycyjne struktury wiedzy (w naukach społecznych) „wrażliwa" na kontrowersje społeczne. Tożsamość systemu jest tworzona na bazie chwiejnej równowagi pomiędzy auto- oraz allopoietyczną zasadą reprodukcji. Przykładem takich rytualnych pojedynków, dyskusji, które kształtowały zbiorową tożsamość analizowanej sieci blogów, są debaty ze zwolennikami medycyny „alternatywnej”, np. skupiające się wokół bloga www. astromaria.wordpress.com. Innym ważnym punktem tworzenia tożsamości jest polemika ze środowiskiem skupionym wokół portalu Fronda.pl, prostowanie informacji dziennikarskich z portali internetowych etc.

Ważnym punktem odniesienia i elementem strategii retorycznej jest wspomniane już, niezbędne odsyłanie do oficjalnych baz danych ${ }^{28}$, co dobrze oddaje powszechnie używana fraza: dajesz zdjęcie (link) albo się nie wydarzyło ${ }^{29}$. Linki są na tyle istotne dla spójności grupy i strategii potwierdzania wiarygodności, że powstała netykieta dotycząca ich zamieszczania, np. zwalczane jest spamowanie, a także publikowanie dużej liczby linków, które są często wklejane przypadkowo, mają bowiem na celu tylko zrobienie wrażenia $^{30}$. Powszechne jest sprawdzanie wiarygodności i adekwatności linków, a zamieszczanie linków nieadekwatnych, przypadkowych jest silnie piętnowane.

Występujące tendencje autopoietyczne wiążą się też $\mathrm{z}$ wytwarzaną zwrotnie samorefleksją, samoświadomością w analizowanym środowisku; oto przykłady:

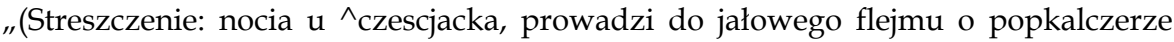
i o to, czy biurowa klasa średnia woli Egipt czy Tunezję, nocia ${ }^{\wedge}$ mrw, w komciach panoszą się jacyś nieogarnialni buce, WO przychodzi z obroną, no i skutek jest taki, że prawicowi blogerzy śledczy tracą kontakt z rzeczywistością..."31.

${ }^{28} \mathrm{~Np}$. Kłamiesz. Nawet FDA, tłumaczac przyczyny wycofania thimerosalu, stwierdziło, że czyni to raczej pod presją opinii publicznej niż wyników jakichkolwiek badań, http://www.fda.gov/ BiologicsBloodVaccines/Vaccines/QuestionsaboutVaccines/UCM070430, http://www.fda.gov/BiologicsBloodVaccines/SafetyAvailability/VaccineSafety/UCM096228, źródło: http:/ / blogdebart.pl/2012/02/29/powrot-dzieci-marnotrawnych/[dostęp: 7.11.2012].

29 Pics or it didn't happen - to określenie na wymóg dowodzenia własnych twierdzeń poprzez pokazanie zdjęcia potwierdzającego opowieść (często będzie to skan, zrzut ekranowy), http:// www.urbandictionary.com/define.php?term=pics $\% 20$ or $\% 20$ it $\% 20$ didn't $\% 20$ happen [dostęp: 7.11.2012].

30 Przypomina to nadmierne cytowanie często przypadkowych źródeł w artykułach naukowych.

${ }^{31} \mathrm{http}: / /$ hejterzymy.blox.pl/tagi_b/177248/badzmy-powaznymi-ludzmi.html [dostęp: 7.11.2012]. 
Innym przykładem jest tworzenie historii sporu, który osiągnął takie rozmiary, że nie wystarczyły już tylko komentarze, ale dyskusja toczyła się pomiędzy notkami, a ponadto $\mathrm{w}$ dziesiątkach komentarzy pod nimi:

„Jest już piąta notka (licząc niniejszą za numer cztery).

Oraz szósta.

A także siódma.

Koniec na tym? Nieeee, ósma" 32 .

Dyskusje wewnątrzśrodowiskowe często ujawniają różnice i podziały, co powoduje, że samorefleksyjna zwrotność komunikacji zabezpiecza częściowo przed zamknięciem środowiska.

\begin{abstract}
„Na blogach ttdkn i okolic oraz na blipie przez kilka dni toczyła się wielka bitwa na temat proponowanego przez minister Kopacz przymusu badań cytologicznych i mammograficznych dla kobiet powyżej pięćdziesiątego roku życia. [...] Duża część środowiska podzieliła się na dwie grupy. [...]

Tyle tytułem wstępu, dla osób, które wejdą na tę notkę z zewnątrz ttdknowskiej blogosfery. Jest to oczywiście duże uproszczenie. Dla pełnego obrazu polecam lekturę notek (oczywiście z komentarzami pod spodem): mdh, tram_way, szprota, btd, czescjacek, sendai_a, jaszczomp. Polecam też dyskusję, która wysypała się już dawno temu (jak widać temat powraca) pod jedną z notek wo"33.
\end{abstract}

Dodatkowym elementem spajającym komunikacyjnie sieć tworzącą „rozproszoną" bazę danych i „rozproszonego” eksperta jest system tagów pomagający porządkować zawartość dyskusji. Jest on zapożyczony z komunikatora blip.pl, ale upowszechnił się także poza nim, na blogach oraz w innych sieciach społecznościowych: Facebook, Google plus. Przykładowe tagi: \#rapiery (oznaczający żmudną, zbyt szczegółową dyskusję, szczególnie na tematy historyczne), \#ttdkn-męskamuzyka (tag krytycznie wskazujący na mizoginiczny charakter danej dyskusji), \#ttdkn-lewica. System tagów doczekał się nawet próby opracowania teoretycznego ze strony jednego zblogerów:

„Tagowanie jest rodzajem metkowania; w ogólnym przypadku to czynność o charakterze semiotycznym: jest sobie przedmiot, a potem (czasem przedtem) przychodzi ktoś i doczepia do przedmiotu znak. O, to-tu jest serkiem za 4,37, a tamto - ulicą jednokierunkową. Kiedy zarówno przedmiot, jak i metka-znak są tekstami - mamy do czynienia z tagowaniem. W takim HTMLu na przykład, fragmenty tekstu są otagowane, by wskazać jego strukturę i zalecany sposób nadania mu formy (ekranoczy typograficznej). Bardzo częstym - jeśli nie najczęstszym ostatnio - użyciem ta-

\footnotetext{
32 http:/ / nameste.litglog.org/2011/05/superbohater-wali-z-prawej/ [dostęp: 7.11.2012].

33 http:/ / lewydolny.pl/2011/05/najpierw-trzeba-zasypac-przepasc/ [dostęp: 7.11.2012].
} 
gowania są krótkie metki opisujące zawartość tekstu, np. ta blogonota jest ometkowana metką z językiem" 34 ,

i dalej:

\begin{abstract}
„A tymczasem - choć początkowo hashtagi spełniały jedynie klasyczną rolę znaczników klasyfikacji - pożytki z tego urządzenia językowego są wprost niesłychane. To tylko blogonota, a nie Ogólna Teoria Hashtagu, więc bardzo skrótowo, nie po porządku, a za to pokrótce, wyłuszczę, w czym rzecz. Najważniejsze (pierwsze najważniejsze) jest to, że hashtag przestaje być «sobie» (przestaje być «zewnętrzną metką») i wchodzi do wewnątrz wypowiedzi, nadając jej zarazem inny wymiar, a nawet - jeden z wielu innych wymiarów. Dzięki hashtagom tekst - pozostając zwięzłym, a więc nadal czytable - zawiera w sobie komentarz-do-samego-siebie, poziom meta. Ale to dopiero początek. Pokazywałem już znaczenie i działanie tagu \#ludzie-którzy, a właściwie meta-hashtagu, bo tagiem pierwszego stopnia (w ZEROLANGU wg Lema \#link: Golem XIV) jest \#ludzie-którzy-gryzą-marchewkę, sam w sobie potężny generator znaczeń. Metatag \#ludzie-którzy jest znakiem (w ścisłym semiotycznym sensie) całej teorii zachowań i rozumień, wewnątrztekstowej oczywiście. Pod warunkiem, to jasne, że będzie jako taki rozpoznany, że stanie się cegiełką idiolektu. Co jest procesem trwającym w czasie, niezadekretowanym przez jakieś reguły białego człowieka i estety, jest praktyką językową (komunikacyjną) anarchiczną, spontaniczną i twórczą \#luz-i-sens. Bawi \#uczy zachęcając zarazem do działania \#rozróba-w-języku zasysającego otoczenie w wir myślącej interakcji. I to jest to drugie najważniejsze" 35 .
\end{abstract}

Powyższe cytaty wskazują wyraźnie, na jakim poziomie teoretycznym odbywa się proces autorefleksji we wspomnianym środowisku. Widać też, ile pojęć i odniesień jest czytelnych tylko dla uczestnika analizowanej sieci blogów.

\title{
7. „ROZPROSZONY EKSPERT” I „ROZPROSZONA” BAZA DANYCH A KRĄŻENIE FAKTÓW NAUKOWYCH
}

Analiza sieci blogów to dobre potwierdzenie intuicji Latoura dotyczących tworzenia i funkcjonowania faktów naukowych. Zaproponował on alternatywny do tradycyjnego sposób ich rozumienia. W klasycznym modelu zwykle relację nauki z jej otoczeniem społecznym ujmujemy poprzez proste rozróżnienie na kontekst i otoczenie. Rdzeń - „twarda" nauka - jest ceniony wyżej niż jej „miękkie” pobocza. W toczonej od lat debacie dotyczącej internalizmu i eksternalizmu ze scholastyczną cierpliwością kolejni dyskutanci zastanawiają się nad tym, które czynniki są zewnętrzne, a które

${ }^{34}$ http://nameste.litglog.org/2011/02/tags/ [dostęp: 7.11.2012].

35 Ibidem. 
wewnętrzne w stosunku do nauki. Latour wielokrotnie krytycznie odnosił się do samego sporu internalizm-eksternalizm, pokazując jego bezzasadność. Było to szczególnie widoczne w pracy Pasteurisation of France i w artykule Dajcie mi laboratorium, a poruszé świat.

Opisując odkrycie Pasteura dotyczące wąglika, który w owym czasie dziesiątkował bydło, Latour wskazał na złożony charakter sukcesu uczonego i dość specyficzny sposób istnienia jego laboratorium. Sukces był możliwy, gdyż Pasteur musiał zmobilizować ogromną sieć sojuszników: drożdże, szczepionki, bakterie, mleczarzy, higienistów, weterynarzy etc. Wszystkie powyższe elementy musiały zostać przez niego włączone w sieć relacji. Wymagało to hodowli bakterii, opracowania szczepionek, przekonania mleczarzy do poniesienia kosztów produkcji, zainteresowania weterynarzy, przekonania lekarzy etc. Uwieńczeniem tych wysiłków była szczepionka. Badanie laboratoryjne mogło „działać” tylko wtedy, kiedy było nieustannie przenoszone pomiędzy badaniem środowiska na "zewnątrz" i tworzeniem sztucznego „środowiska” wewnątrz laboratorium. Samo laboratorium stawało się raczej bytem sieciowym, rozciągniętym pomiędzy polami, rolnikami, naukowcami a opinią publiczną. Ciągła aktywna mobilizacja każdego z elementów była gwarantem sukcesu i Pasteura, i szczepionki. Zanik któregoś elementu, np. skrajny sceptycyzm co do roli bakterii (dyktowany choćby światopoglądem religijnym), mógłby spowodować brak zainteresowania szczepionką i w tym sensie zniweczyć jej skuteczność. Pasteur zyskał moc zmiany społeczeństwa dzięki temu, że potrafił wyizolować mikroba, zamknąć go w laboratorium, osłabić i wykorzystać do produkcji szczepionek. Równocześnie i równolegle musiał on całą Francję poddać "laboratoryzacji”, to znaczy rozciągnąć na obszar całego kraju warunki, które gwarantowały skuteczność działania szczepionek. Widzimy zatem, że mówienie o wnętrzu i zewnętrzu nauki jest archaizmem, który nie oddaje dobrze realnej praktyki naukowej. W późniejszej książce Nadzieja Pandory. Eseje o rzeczywistości w studiach nad nauką ${ }^{36}$ Latour rozwinął swoje stanowisko i przedstawił alternatywny model funkcjonowania nauki. Model ten, co ważne, w znacznej mierze potrafi wytłumaczyć praktykę naukową bez konieczności odwołania się do debaty internalizm-eksternalizm. We książce tej uczony wskazał pięć najistotniejszych „pętli”, po których krąży fakt naukowy, zaś pętle te - połączone ze sobą - stanowią model praktyki naukowej. Wymieńmy je: Mobilizowanie świata, Autonomizacja, Sprzymierzeńcy, Reprezentacja publiczna, Powiazania i węzły. Mobilizowanie świata to "pakowanie świata w słowa", to praktyka laboratoryjna, eksperyment, możliwość

${ }^{36}$ B. Latour, Nadzieja Pandory. Eseje o rzeczywistości w studiach nad nauka, Toruń 2013, rozdział „Krwiobieg nauki. Przykład naukowej inteligencji Joliota”; por. także K. Abriszewski, Wszystko otwarte na nowo..., s. 30-33. 
studiowania "księgi natury”. Autonomizacja to wpisywanie się w rolę zawodową, funkcjonowanie w ramach kolektywów badawczych (używając terminu Flecka). Sprzymierzeńcy to przede wszystkim pozyskiwanie funduszy, instytucjonalizacja "zainteresowania”. Reprezentacja publiczna to "oswajanie" ludzi z badaniami, budowanie zaufania do nauki, relacje z mediami i teksty popularnonaukowe. Wreszcie powiązania i węzły to pętla nauki, która łączy wszystkie inne pętle, są one bowiem od siebie nierozdzielne. $W$ tym prostym modelu możemy dokładnie ukazać, jak nauka się przemieszcza, jak funkcjonuje $\mathrm{w}$ zbiorowym złożonym układzie zmiennych.

Przywołałem w skrócie "krążeniowy” model funkcjonowania nauki i tworzenia faktu naukowego, gdyż pokazuje on dobrze wyzwania, jakie wobec tradycyjnych struktur wiedzy w naukach społecznych stawia wspólczesna praktyka technonaukowa i wytwarzane przez nią kontrowersje. Nauki społeczne, posługując się przestarzałym schematem: kontekst-otoczenie, nie są $\mathrm{w}$ stanie formułować adekwatnej diagnozy sytuacji i w związku z tym nie są w stanie proponować żadnych skutecznych recept. Nauki społeczne nie mogą też pełnić funkcji eksperta $\mathrm{w}$ odniesieniu do coraz to liczniejszych sporów i kontrowersji rozrywających współczesne, technonaukowe społeczeństwo.

\section{PŁYNĄĆ ZA INNOWACJĄ I KONTROWERSJAMI}

Posiłkując się modelem Latoura, stawiam mocną tezę, że eksperci zajmujący się technonauką i wynikającymi z jej praktyki kontrowersjami sami również muszą „rozpaść” się na kilka „specjalności” zależnych od poszczególnych pętli. Krążącym "faktom” naukowym odpowiadać powinni „krążący eksperci”. Powinni oni także dysponować jakimiś formami „rozproszonych" baz danych, które byłyby równocześnie źródłem wiedzy oraz zapisem, mikrohistorią działania eksperta. „Rozproszona”, aktywnie tworząca się $\mathrm{w}$ trakcie badania i toczących się sporów baza danych pozwala na przezwyciężenie tradycyjnego, "zwierciadlanego" sposobu traktowania tekstów naukowych. Aby być skutecznym ekspertem w zmieniającym się błyskawicznie świecie, nauki społeczne powinny wytworzyć narzędzia, które będą w stanie wytwarzać wiedzę w „czasie rzeczywistym”, modelować spory „na gorąco”.

Nie oznacza to oczywiście, że mamy porzucić tradycyjne zadania nauk społecznych i zaprzestać pisania tradycyjnych tekstów. Te jednak pełnią inne funkcje, są "czarnymi skrzynkami”, stabilizują dyskurs, tworzą stałe punkty odniesienia. Niestety, nauki społeczne w Polsce, ze względu na ich 
relatywnie słabe wewnętrzne skomunikowanie, brak pętli zwrotnych, przywiązanie do modelu kontekstu/otoczenia, nie są w stanie pełnić ważnych społecznie funkcji. Są raczej zajęte działalnością utrwalającą, stabilizującą dotychczasową wiedzę, a przez to bezradne wobec palących problemów współczesności. Celem analizy blogów skupionych pod szyldem TTDKN było pokazanie specyficznej bazy danych, która w dużej mierze nie służy redukcji złożoności, ale pozwala poruszać się $\mathrm{w}$ złożonym świecie kontrowersji naukowo-społecznych. Stawiam mocną tezę, że przyszła reforma struktur wiedzy w naukach społecznych zyskałaby wiele, gdyby posiłkowała się doświadczeniami tej i podobnych struktur oddolnego wytwarzania wiedzy. Parafrazując słowa Krzysztofa Abriszewskiego, w dzisiejszym świecie nie sposób wypić oceanu wiedzy, trzeba nauczyć się pływać w złożonym świecie technonaukowego społeczeństwa. Nauki społeczne mogą tylko zyskać, ucząc się od tych, którzy może i amatorsko, ale próbują pływać w żywiole sporów i kontrowersji naukowo-społecznych.

\section{BIBLIOGRAFIA}

Abriszewski K., Trzecia fala. Ludwik Fleck i antropologia laboratorium, 2009, http://fleck. umcs.lublin.pl/teksty.abriszewski2009a.htm [dostęp: 25.10.2012].

Abriszewski K., Wszystko otwarte na nowo. Teoria Aktora-Sieci i filozofia kultury, Toruń 2010.

Beck U., Społeczeństwo ryzyka. W drodze do innej nowoczesności, Warszawa 2002.

Bińczyk E., „Ucieleśnione” $i$ ",rozproszone” poznanie a obraz praktyk naukowych, [w:] Nauka w filozofii. Oblicza obecności, red. S. Butryn, M. Czarnocka, W. Ługowski, A. Michalska, Warszawa 2011.

Clark A., Chalmers D., Umyst rozszerzony, [w:] Analityczna metafizyka umystu. Najnowsze kontrowersje, red. M. Miłkowski, R. Poczobut, Warszawa 2008.

Diamond J., Upadek, Warszawa 2007.

Flyvbjerg B., Making Social Science Matter: Why Social Inquiry Fails and How It Can Succeed Again, Cambridge 2001.

Goody J., Logika pisma a organizacja społeczeństwa, przekład, wstęp i redakcja G. Godlewski, Warszawa 2006.

Havelock E.A., Muza uczy się pisać. Rozważania o oralności i piśmienności w kulturze Zachodu, przekład i wstęp P. Majewski, Warszawa 2006.

Heidegger M., Bycie i czas, Warszawa 1994.

Hutchins E., Cognition in the Wild, Cambridge, MA 1995.

Johnson S., Where Good Ideas Come From: The Natural History of Innovation, Riverhead Hardcover 2010.

Latour B., Nadzieja Pandory. Eseje o rzeczywistości w studiach nad nauka, Torun 2013.

Nowak A.W., Doświadczenie codzienności u Martina Heideggera, [w:] Doświadczenie, red. T. Buksiński, Poznań 2001.

Nowak A.W., Ontological Imagination: Transcending Methodological Solipsism and the Promise of Interdisciplinary Studies, [w:] Language, Literacy, and Media Theory: Exploring the Cultural History of the Extended Mind, "Avant” 2013, vol. IV, iss. 2. 
Olson D.R., Papierowy świat. Pojęciowe $i$ poznawcze implikacje pisania $i$ czytania, wstęp i redakcja naukowa G. Godlewski, Warszawa 2010.

Podgórski J., Główne założenia poznania rozproszonego a sposób opisywania procesów poznawczych w określonej wspólnocie, „Homo Communicativus” 2008, nr 1(3).

Stankiewicz P., Ryzyko i konflikt. Strategie zarządzania konfliktami technologicznymi w Polsce, niepublikowana praca doktorska dostępna online: http://polska-wolna-od-gmo. org/doc/Piotr_Stankiewicz_PhD.pdf.

Tuchańska B., O Sokalu z Bricmontem, Latourze i o tym, co z tego (nie) wynika, "Nauka” 2006, nr 1 .

Wyzwania wobec nauk społecznych u progu XXI wieku, do druku przygotował A. Flis, Kraków 1999.

Zybertowicz A., Przemoc i poznanie: studium z nie-klasycznej socjologii wiedzy, Torun 1995.

\section{Źródła internetowe}

http://blogdebart.pl/2009/09/25/jak-pije-sie-nafte/ http://blogdebart.pl/2010/03/17/dalsze-przygody-swinki-w-new-jersey/ http:/ / blogdebart.pl/2010/07/29/witamina-w-cudzyslowie/ http://blogdebart.pl/2011/05/25/starozytne-madrosci-profesora/ http:/ / blogdebart.pl/2012/02/29/powrot-dzieci-marnotrawnych/ http://hejterzymy.blox.pl/tagi_b/177248/badzmy-powaznymi-ludzmi.html http://lewydolny.pl/2011/05/najpierw-trzeba-zasypac-przepasc http:/ / nameste.litglog.org/2011/02/tags/ http://nameste.litglog.org/2011/05/superbohater-wali-z-prawej/ 